\title{
Influence of Community Forest Association Activities on Dryland Resources Management: Case of Kibwezi Forest in Kenya
}

\author{
John Mwendwa Mugambi ${ }^{1,}$, , Jane Kagendo ${ }^{1}$, Mulaha Kweyu ${ }^{2}$, Musingo Tito Edward Mbuvi ${ }^{3}$ \\ ${ }^{1}$ Department of Languages and Humanities, School of Social Sciences, Mount Kenya University, Nairobi, Kenya \\ ${ }^{2}$ Department of Geography, School of Humanities and Social Sciences, Kenyatta University, Nairobi, Kenya \\ ${ }^{3}$ Department of Research and Development, Monitoring and Evaluation Unit, Kenya Forest Research Institute, Nairobi, Kenya
}

Email address:

bestmugambi@gmail.com (J. M. Mugambi)

${ }^{*}$ Corresponding author

\section{To cite this article:}

John Mwendwa Mugambi, Jane Kagendo, Mulaha Kweyu, Musingo Tito Edward Mbuvi. Influence of Community Forest Association Activities on Dryland Resources Management: Case of Kibwezi Forest in Kenya. International Journal of Natural Resource Ecology and Management. Vol. 5, No. 3, 2020, pp. 119-128. doi: 10.11648/j.ijnrem.20200503.16

Received: August 6, 2020; Accepted: August 17, 2020; Published: September 3, 2020

\begin{abstract}
Gazetted forests in Kenya are owned and managed by the government through Kenya Forest Service. Other stakeholders including communities formally participate in forest management through Participatory Forest Management, concessions and leasehold. In each management regime the forest has to be well managed and the community continue accessing forest products. The aim of this paper was to investigate whether Community Forest Association activities lead to improved forest cover in a leased forest. The study adopted a descriptive survey design where both qualitative data and satellite data was collected. A sample size of 139 individuals was issued with questionnaires and 5 key informants were interviewed. Satellite imagery was used to quantify changes and trends in forest cover of Kibwezi forest for ten years. Findings of the study established that infrastructural development had a great effect on destruction of forest cover in Kibwezi forest. There was significance relationship between community participation and improvement of forest since Chi square results were $\left(\chi^{2}\right.$ $=27.631, \mathrm{df}=9,0.001)$. This research recommends that there should be deliberate action by stakeholders to give community forest association incentives to operate optimally. The improvement of the forest was partially contributed by presence of community forest association during inception of project but later David Sheldrick Trust which fenced the forest.
\end{abstract}

Keywords: Community Forest Association, Leasehold, Forest-cover, Forest Destruction, Conservation, Incentives

\section{Introduction}

Rapid dryland forests cover change has attracted global attention for urgent actions by all stakeholders to ensure it is conserved because it is an important ecosystem [1]. The first Forest Research Assessment (FRA) in 1948 showed that the world had $66 \%$ of its land covered by forest; more than half of this area had been deforested by 2018 because globally, only $30.6 \%$ of total land area was covered by forest in the year 2018 [2]. This is an acute reduction from findings contained in FRA 2015 report which showed $31.6 \%$ of land was covered by forest in 1990 [3]. If this trend continues, it will take about one century for the world forest to be completely cleared. Sub-Saharan African land mass covered by forest is estimated to be $27.1 \%$ [2]. If urgent actions will not be taken, dryland forest shall be cleared within short period of time (Bekele, et al., 2016). While there has been improvement in the world forested area estimates in the last decade, African countries have experienced a decline in forest cover [2]. Kenya has a forest cover of 7.8\% [3].

There is general agreement that Participatory Forest Management (PFM) leads to forest cover improvement [4, 5]. Dryland forest is one of the most important type of forest that provide livelihood to millions of the people globally. If these type of forest are not well managed, they will be degraded leading to loss of biodiversity and livelihood of very many people [6]. Globally, there has been a change of traditional tactics of forest protection whereby only government could 
protect forest to modern school of thought which advocates for involvement of stakeholders in management. This has influenced the need to encompass adjacent communities' participation in management of forest leading to introduction of PFM [7]. When community is excluded in forest conservation, they tend to destroy forest as predicted in common pool scenario [8]. Countries like Nepal have very successful PFM due to their long experience in this kind of forest management. Degradation of forest in Nepal reduced when communities owned forest [9]. For African forest to be restored, urgent actions must be taken [2]. These actions should include; participation of both community forest dwellers and the forest adjacent communities in conservation of forest and empowering communities to improve the status of the forest more than government institution since they are connected to the realities on the ground [10].

Many African nations now advocates for community participation in forest conservation as opposed to traditional methods where only government had exclusive rights in protecting, conserving and management of environment [8]. In Ethiopia, PFM was found to be one of the best methods of forest management [4]. To succeed in PFM, community should be included in all levels which include formulation of law, planning, implementation, monitoring and evaluation [11]. Although PFM is one of solutions of forest degradation, there are very few nations where it operates optimally to yield desired results [4].

Globally, Brazilian Amazonian communities successfully negotiated with the government and came up with the solution which mitigated forest degradation through community participation. This brought solution and forest was saved from degradation $[7,12]$. The community is the primary user of the forest and ultimate beneficiaries of a healthy forest hence they should always be involved in forest management for optimum results [13]. Globally, first dryland assessment was done in 2016 to assess extent to of dryland forest. This shows that little attention has been laid on dryland forest even in global scale although they are as important as any other type of forest. Dryland forest also attract little research although they are as important as any other type of forest [13]. Although dryland contain most threatened biomes, very little attention has been drawn hence need for comprehensive research [14].

In Africa, there has been effort to establish PFM in some countries. Very few countries with dryland forest have a wellestablished PFM [4]. Ethiopia is one of countries that has managed to reduce deforestation through PFM. These initiatives faced several challenges that threatened their existence which ranged from lack of enough consultation in making law, financial constrains among others [15]. The dryland forests have historically been labelled as less productive hence little investment done on them leading to their degradation [16].

In Kenya, communities have been credited for protecting forest historically as was demonstrated by Arabuko Sokoke community who acted smart to prevent settling squatters in forest [17]. Although Kenya is $80 \%$ dry, there is a handful researches done on participatory management of drylands forest though they have been destroyed to unprecedented levels leading to the loss of livelihood [18]. Despite these destructions, Community Forest Associations (CFA) in Kenya have not been fully operationalised despite enactment of law in 2005 and its amendment in 2016 [19].

Although drylands forest is one of the most important common pool resources in Makueni County, little attention has been put on it. Drylands forest have become soft target for the wood curving, charcoal burners, logging for poles and clearance for settlement since little attention has been put on them [18]. In Makueni, only $2.3 \%$ of land is covered by forest. This is less than a quarter of constitutional 2010 recommendation of $10 \%$ of land should be forested [20]. Kenyan constitution 2010 recommends that more than $10 \%$ of total land area of the nation should be covered by forest. However, this has not been achieved and forest degradation has continued. The situation in Makueni County is not different from other parts of Kenya where forest cover remains relatively low. The county's forest cover is four times less than constitutional recommendation of $10 \%$. The government introduced PFM as an alternative forest management that enables communities participate through Community Forest Associations (CFAs) to improve the forest management.

In Kibwezi Sub County of Makueni County, drying of Kambu River, Mutitu Andei and turning of great Kiboko river into seasonal rivers is an indicator of the degradation in Kibwezi forest [21]. This shows how this kind of forests have been neglected over time. Kibwezi being a dryland forest, there is need to conserve this forest to continue rendering environmental services. In Kenya, PFM was found to improve forest cover [22]. Community forest association were introduced in Kenya to help the government in improving forest cover [17].

Despite the presence of CFA in Kenya, forest conditions are not improving. Additionally, despite formation of CFA, little is known about their activities in Dryland forest especially that has been leased. Since the formation of the CFA, there is little that is known on effects of community participation in dryland resource management and more specifically a forest under leasehold. Against this background, this research was conducted on how participation of community can or hinder conservation of dryland forest. The persistence degradation of forests in Kenya necessities this study in order to assess the influence of CFA activities on improvement of dryland resource management.

\section{Theoretical framework}

This paper was based on common pool theory developed by Ostrom (1990). It explains that it is very difficult to alienate people from using common pool resources and when one user uses these resources it leads to reduction of benefits of other users [23]. The theory states that people are very irrational but they can act rationally if certain conditions are met. If the natural resources are not carefully managed, there is risk of people exploiting them unsustainably causing 
tragedy of commons [24]. To avoid the tragedy of commons and achieve better outcome, natural resources must be governed according to the rule of law for public good. The community must be involved in management of their resources to avoid over exploitation of common pool resources [25].

This theory provides a strong foundation of assessing how community participation influences dryland forest resource management. Based on this theory, if forest resources users are not involved in management, they will most often destroy the resources [25]. This theory provides the basis of finding out how community forest activities have influenced communities to take active roles in forest conservation.

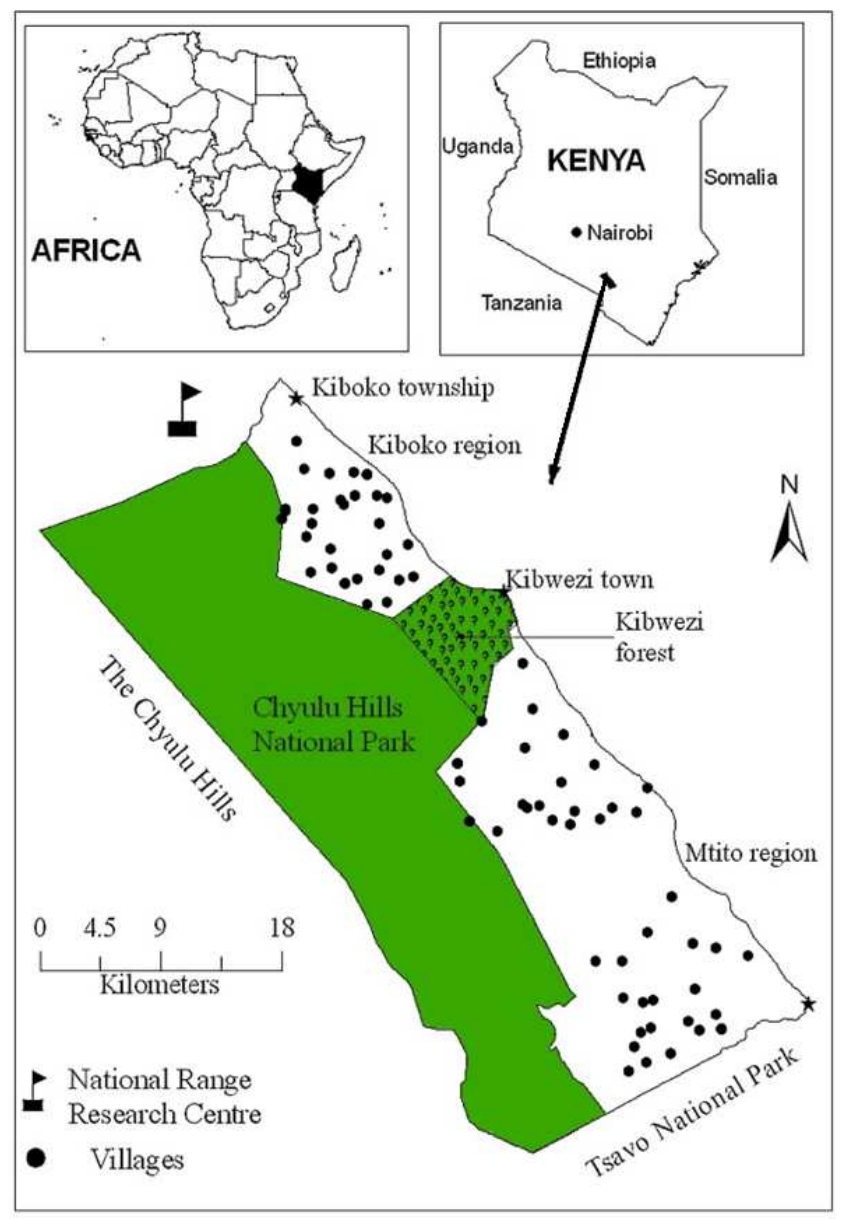

Source: David Sheldrick 2020

Figure 1. Kibwezi forest map (study location).

\section{Materials and Methods}

\section{Location of the Study}

Kibwezi forest is located in Kibwezi Sub County of Makueni County Kenya and covers an area of 5849 hectares. The forest is located in the periphery of Chyulu ecosystem [21]. It is located at latitude $-2.43 \mathrm{~S}$, longitude $37.91 \mathrm{E}$ and besides Nairobi Mombasa road; approximately $190 \mathrm{~km}$ South East of Nairobi [21]. It extends to Chyulu national park to the West and borders Kibwezi town to the South East. The Mombasa-Nairobi Oil pipeline crosses the forest.
Kibwezi forest is located in semi-arid region in Makueni County. The altitude ranges from 900-1015 metres above sea level. Underground Umani springs passes through the forest and spring out in Kibwezi town. The area receives a mean annual rainfall of 250-350 mm per year. Due to its proximity to the Equator, it receives bimodal rainfall. It receives short rains between November and December while long rains are experienced between March and April. The area has moisture indices of $32 \%$. February and October are the hottest months while July is the coolest [21].

Kibwezi Sub County has a population of 248,704 people, distributed over an area of 52,979 square kilometres hence sparsely populated. The area has population density of sixty two person per square kilometer [26]. The people around the forest are farmers, artists and traders. The area is categorised as agro-pastoralism since subsistence crop farming and animal keeping are dominant. They keep domestic animals such as cows, goats, hens and sheep. Some people do wood curving for commercial purpose. Farmers comprise $78 \%$ of the residents, mostly undertaking subsistence farming of beans and maize. Only $10 \%$ of the residents have formal employment while $12 \%$ are self-employed [21].

Sample and Sampling Methods

This study adopted a descriptive survey research design in order to meet the research objective. Descriptive research design is very useful in describing current status of a phenomenon [27]. Based on this research design, the study attempted to seek responses to research questions relating to community forest activities that influenced improvement of dryland resource management. The target population for this study was 2,585 which comprised heads of households living around Kibwezi forest and government workers in Kibwezi forest. This research paper adapted formulae proposed by [28] to compute the sample size for the study since the sample population was less than ten thousand.

$$
n=\left(z^{2} p q\right) / d^{2}
$$

Where $n=$ desired sample size

$z=$ standard normal deviation (1.96) for $95 \%$ confidence level $p=$ expected reverence of proportion ( $10 \%$ is recommended hence 0.1 )

$q=1-\mathrm{p}$ therefore $\mathrm{q}=(1.0-0.1=0.9)$

$d=$ statistical significance $(0.5)$

$$
\begin{aligned}
n & =\left(1.96^{2} \times 0.1 \times 0.9\right) \div 0.5^{2} \\
& =139
\end{aligned}
$$

A total of 139 respondents were issued with questionnaires. Out of 139, there were 77 members of CFA while 62 were non-members of CFA. Only 134 questionnaires were returned. Out of 76 CFA members who responded to our questionnaires, 32 were from Kithasyiu area, 18 were from Kaunguni while 16 were from Mikuyuni. Out of 58 non CFA members who responded to our questionnaires, 21 were from Kithasyiu area, 20 were from Kaunguni while 17 were from Mikuyuni.

\section{Data Collection}

Structured questionnaires, interview schedule, observation 
schedule and document analysis guide was used to collect data from respondents. Structured questionnaires had closed ended questions that were simple to analyse and aided in obtaining quantitative data.

Landsat imageries with a resolution of 30 meters were downloaded from United States Geological Survey (USGS).
Geo-referenced and terrain corrected for geometric distortion was done to enable effective matching between location and scenes. To describe the state of the forest, satellites imagery was used. Satellite information was obtained from Landsat 2008, Landsat 2018, ENVI 5.5.1, ArcGIS 10.6.1 as shown in Table 1:

Table 1. Summary Satellite Data Collection and Analysis Tools.

\begin{tabular}{ll}
\hline File/Software & Description \\
\hline Landsat_2008 & February 2008 Landsat 7 ETM+ (Enhanced Thematic mapper Plus) image covering Kibwezi Forest \\
Landsat_2018 & February 2018 Landsat 7 ETM+ covering Kibwezi Forest \\
Shape file & Boundary of Kibwezi Forest \\
ENVI 5.5.1 & Environment for Visualizing Images (Remote Sensing Software) \\
ArcGIS 10.6.1 & Esri Geospatial Analysis and mapping Software \\
\hline
\end{tabular}

Source: ArcGIS 2020

The classification of two Landsat images was used to separating four classes of forest cover namely; wetland, shrubs, forests and bare land. The classes were based on local experiences and exploration with Google earth application. The recommended Intergovernmental panel on Climate Change (IPCC) land cover classification [29] was modified since cropland and grassland were omitted. Statistical test was done to depict the changes in Kibwezi forest cover. Classification of two Landsat images was carried out using ENVI 5.5.1 (Remote sensing software). ArcGIS 10 was used for displaying and subsequent processing and enhancement of derived products. Class labelling was achieved through comparison of the classified image with the original images, use of topographic maps and study area knowledge through local knowledgeable persons assisted to identify the various classes. The data training and maximum likelihood classifier approach were used during supervised classification. Selection of pixels from the image was done to establish thresholds to delineate specific land covers on the ground. A representative set of pixel values for each class was key for the implementation of a supervised classification. Post classification change detection method was applied on the final 2008 and 2018 Kibwezi forest land cover maps. Further statistics of changes were calculated and a general land cover change map derived.

Landsat images used in this research included February $20^{\text {th }}$ 2008 Enhanced Thematic Mapper plus (ETM+) and February $5^{\text {th }} 2018$ ETM+ of path 167 and row 62. Both images were obtained from United States Geological Survey (USGS) through earth explorer user interphase. These images were selected because they were about 85 percent cloud free and near anniversary in their acquisition dates. February is usually a dry period and therefore ideal for mapping vegetation in their natural characteristics. A shape file of the Kibwezi forest boundary layer was obtained from Kenya Forest Service. Topographical maps covering Kibwezi forest was obtained from Kenya's Department of Surveying and Mapping.

Thematic change extraction

The classification of the two Landsat images was aimed at separating four classes namely; wetland, shrubs, forests and bare land. The classes were based on local experiences and exploration with Google earth application. The recommended
Intergovernmental panel on Climate Change (IPCC) on land cover classification was modified since cropland and grassland were omitted. Statistical test was done to depict the changes in Kibwezi forest cover.

Image classification

Classification of the two Landsat images was carried out using ENVI 5.5.1 (Remote sensing software). ArcGIS 10 was used for displaying and subsequent processing and enhancement of derived products. Both unsupervised and supervised classification were used. While undertaking unsupervised classification, the targeted classes as per classification scheme were all coded with particular numbers and each of the spectral classes in the output raster assigned a code corresponding to the class as recommended [29]. Class labelling was achieved through comparison of the classified image with the original images, use of topographic maps and study area knowledge to identify the various classes. However, the output did not yield good results and a supervised classification was undertaken using the prior knowledge of the area and results from unsupervised classification. The data training and maximum likelihood classifier approach were used during supervised classification. Selection of pixels from the image was done to establish thresholds to delineate specific land covers on the ground. A representative set of pixel values for each class was key for the implementation of a supervised classification [30].

\section{Change Detection}

Post classification change detection method was applied on the final 2008 and 2018 Kibwezi forest land cover maps. The two land cover maps were compared pixel by pixel with the final results showing both change-no-change information as well as 'from to' land cover change information. Further statistics of changes were calculated and a general land cover change map was derived. Collect Earth was used for accuracy assessment. The results are shown in chapter four.

Acquisition of data sets

Landsat images used in this research included February $20^{\text {th }}$ 2008 Enhanced Thematic Mapper plus (ETM+) and February $5^{\text {th }} 2018$ ETM+ of path 167 and row 62. Both images were obtained from the United States Geological Survey (USGS) via earth explorer user interphase. These images were selected 
because they were about 85 percent cloud free and near anniversary in their acquisition dates. February is usually a dry period and therefore ideal for mapping vegetation in their natural characteristics. A shape file of the Kibwezi forest boundary layer was obtained from Kenya Forest Service. Topographical maps covering Kibwezi forest were obtained from Kenya's Department of Surveying and Mapping.

\section{Image Preparation and Processing}

The downloaded compressed files were extracted using ENVI 5.5.1 remote sensing software. The two Landsat images were already geo-rectified and consequently geometric correction. The images were re-projected to UTM zone 37 South and subset to the study area using Kibwezi forest boundary shape file. Topographic maps were georectified to their actual latitude and longitudes in the map. Radiometric correction of both Landsat images was undertaken using Radiometric calibration tools within ENVI 5.5.1 remote sensing environment as described by Chander et al [31]. The images were further improved through atmospheric correction using Fast Line-of-sight Atmospheric Analysis of Spectral Hypercube (FLAASH) application within ENVI software.

\section{Results and Discussions}

A response rate of $96 \%$ was attained for this study. The results were therefore adequate for generalization to entire population.

\subsection{Influence of Community Forest Association Activities on Forest Cover Change in Kibwezi Forest}

The respondents' perceptions on how various factors affected forest cover change were sought focusing on Community Forest Association activities on forest cover change in Kibwezi forest as shown in Figure 1. The household respondents indicated that charcoal burning had an influence on forest cover with $(47.8 \%$ of the household respondents agreeing that burning charcoal contributed to destruction of forest while $52.2 \%$ did not agree. The respondents $(72 \%)$ perceived that infrastructure had an influence on forest cover in Kibwezi forest while $28 \%$ did not agree. This shows a significant relationship between infrastructure and forest management. The development of infrastructures in the forest such as standard railway gauge construction, expansion of roads and electricity were threat to the forest after the fencing.

The findings showed that scouts' patrols were the most effective method of forest protection as perceived by $40 \%$ of respondents who confirmed that the community scouts contributed to improvement of the forest to a very large extent but $60 \%$ of the respondents disagreed. This was because of the formally employed scouts by the leasehold holder who do forest patrol and they are more active as they are employed unlike the community scouts who work on voluntary basis. Additionally, the household respondents indicated that fencing had positive influence on forest cover in Kibwezi forest as perceived by $46 \%$ of the respondents agreed while $54 \%$ of the respondents did not agree with this perception as community patrol was perceived to contribute more than fencing. Fencing Kibwezi forest contributed to positive forest cover change through allowing natural regeneration of trees. This was attested by $42 \%$ of the respondents while $58 \%$ of the respondents did not agree with this statement because of the short time since the fence was constructed made it not easy to associate the change to fencing as indicated by Key Informants.

The respondents perceived that the leasehold holder, David Sheldrick Trusts' activities had improved forest cover in Kibwezi forest as indicated by $65 \%$ of the respondents perceiving that there was great improvement in the forest due to measures put by David Sheldrick Trust but 35\% of respondents disagreed to this statement. The findings of this research are in agreement to Marinho et al (2016) who observed that land use was one of the greatest drivers of the forest cover change. These findings also are in consisted with [32] who postulated that fencing forest reduces illegal activities in the forest hence enhancing forest conservation and improve forest cover.

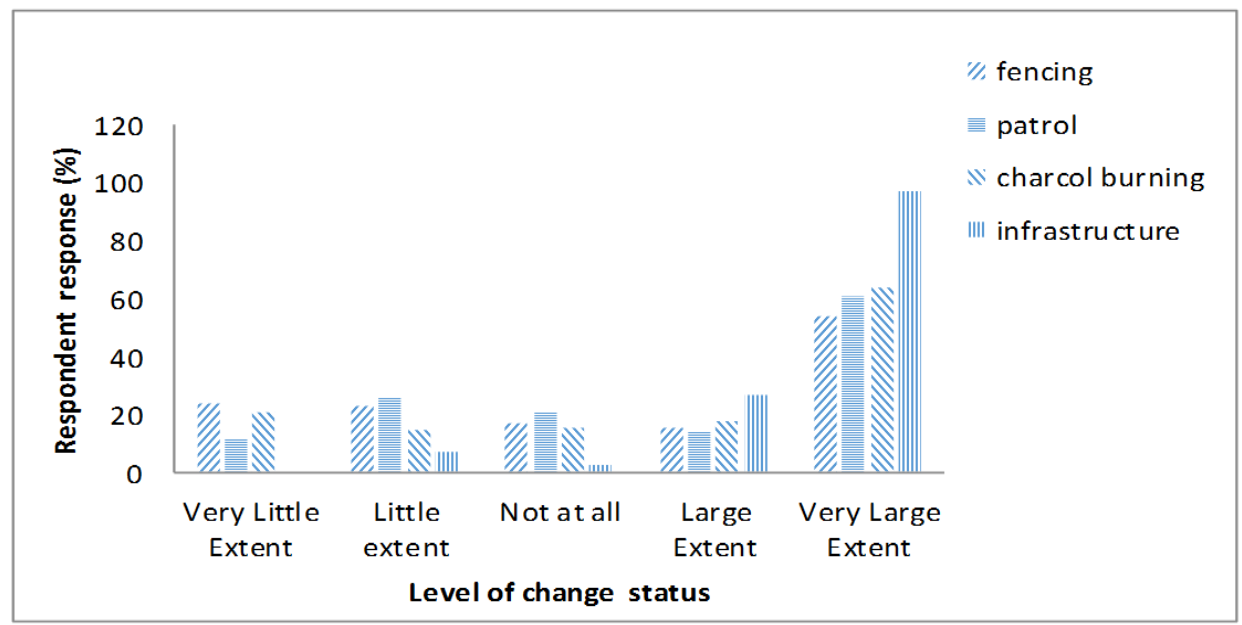

Source: Researcher (2020)

Figure 2. Forest Cover Change. 


\subsection{Geographic Information System}

Geographical Information System was used to describe forest cover change in order to authenticate the household perceptions findings.

Kibwezi Forest Cover Change Between 2008 and 2018
Two land cover maps of Kibwezi forest based on 2008 and 2018 ETM+ Landsat images were produced using supervised classification as shown in Figure 3 consisting of four classes each. The classes were, forest, shrubs, wetland and built and bare as shown in Table 2.

Table 2. Land cover classification scheme.

\begin{tabular}{ll}
\hline Class & Description \\
\hline Wetland & Open water, floating vegetation, permanent papyrus swamps, natural wetland vegetation usually evergreen throughout the year \\
Shrub & This category is characterized by scattered deciduous perennial vegetation of mainly less than $3 \mathrm{~m}$ in height. \\
Forest & Evergreen woody vegetation with interlocking canopy of height above 3m evergreen throughout the year \\
Bareland & Buildings and bare ground usually with no vegetation or houses \\
\hline
\end{tabular}

Source: Researcher (2020)

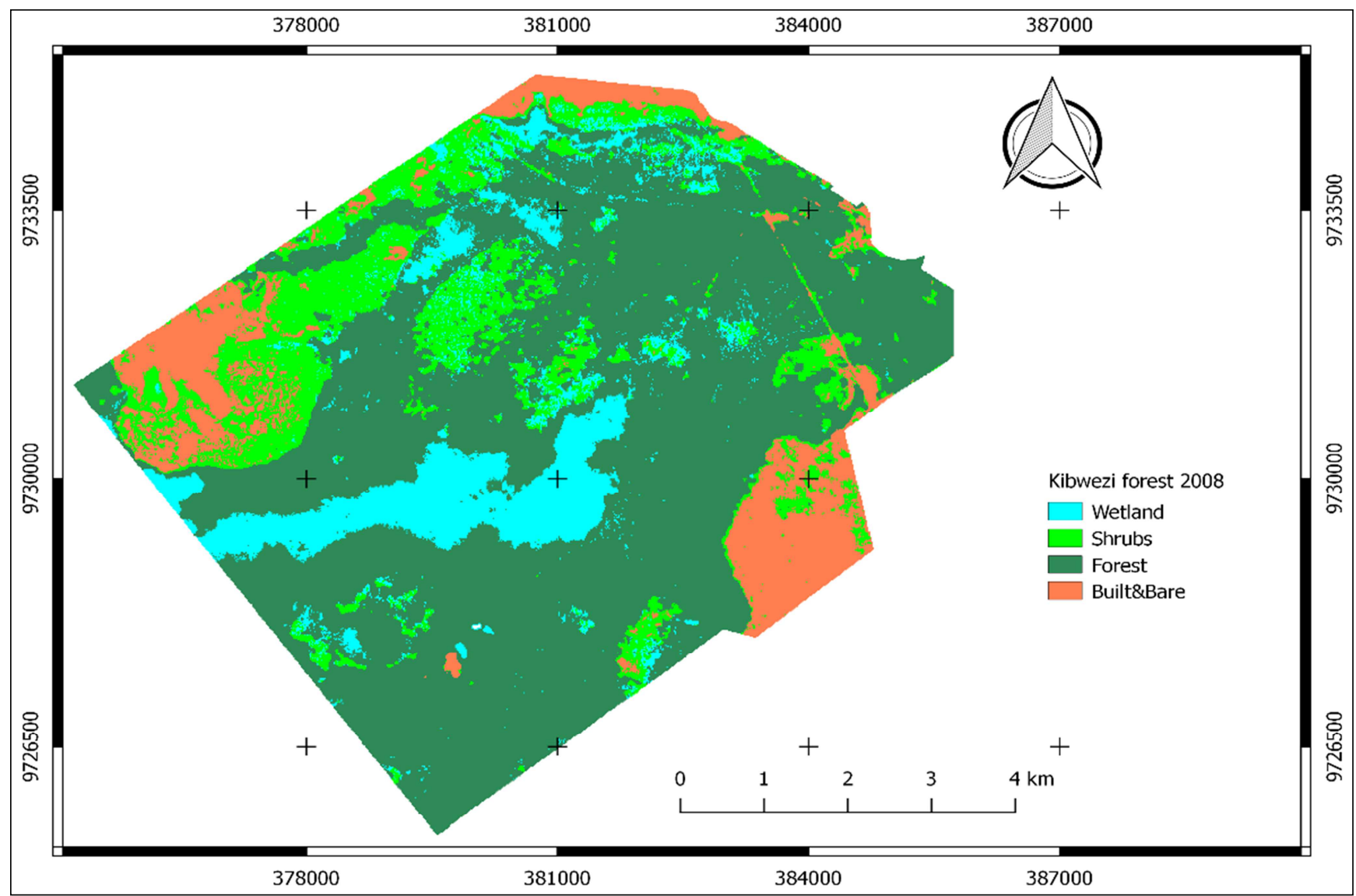

Source: Satellites Images (Field Data 2020)

Figure 3. Kibwezi Forest Land Cover Map for 2008.

The figure 3 represents a map of Kibwezi forest in 2008, five years before the formation of CFA. The characteristics of different classes were calculated and tabulated as in the Table 3.

Table 3. Area statistics for Kibwezi forest land cover in 2008.

\begin{tabular}{lll}
\hline Land cover & Area (ha) & Percent \\
\hline Forest & 3688.67 & 63.09 \\
Shrubs & 813.5 & 23.92 \\
Wetland & 696.22 & 11.91 \\
Bareland & 647.91 & 11.08 \\
\hline
\end{tabular}

Source: Satellites Images (Field Data 2019)

The area statistics of 2008 land cover map shows forest areas covers $63.09 \%$ followed by shrubs $(23.92 \%)$ then wetlands 
(11.91\%) while bare land occupies the least area of about $11.08 \%$ as shown in Table above.

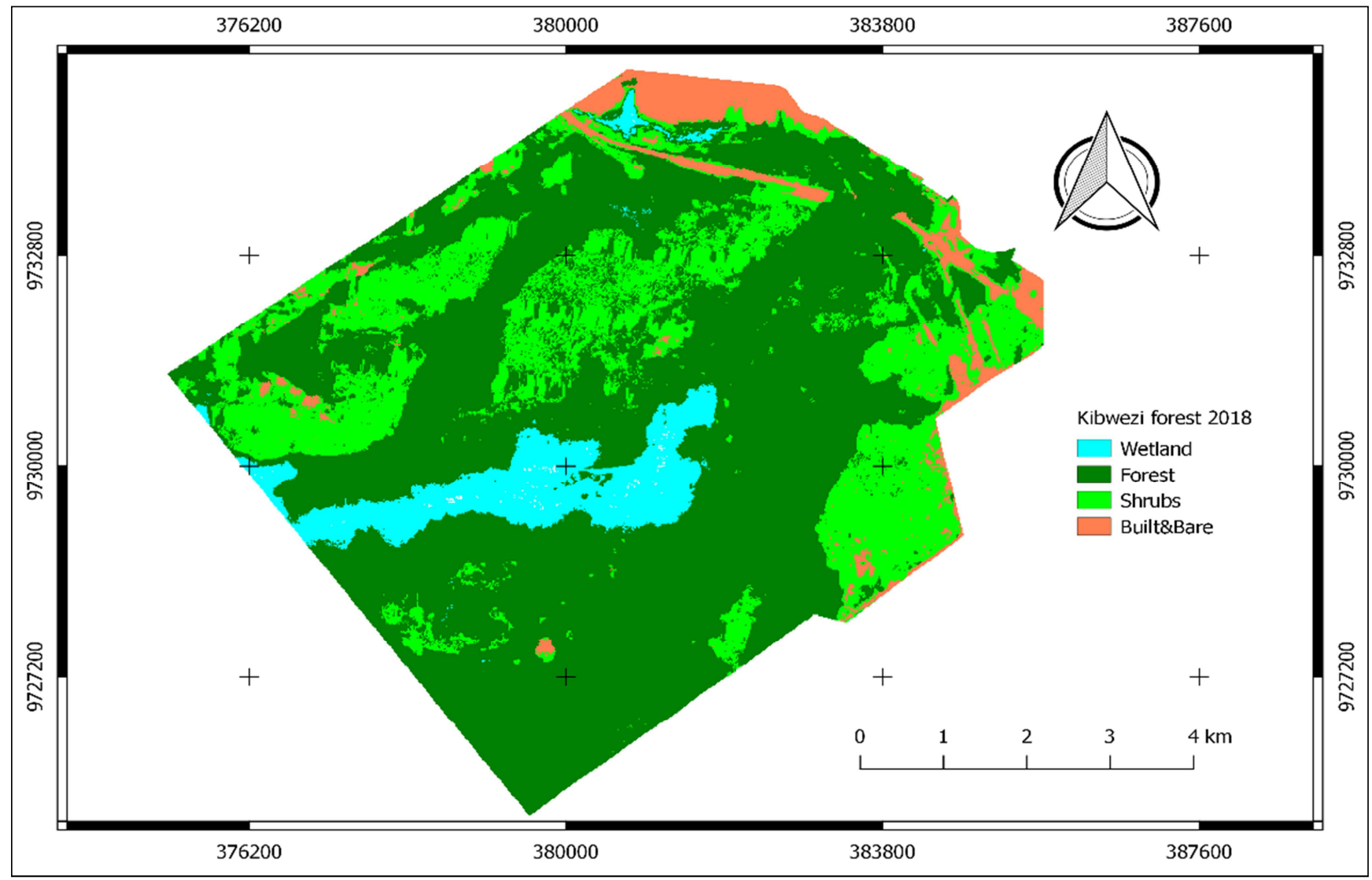

Source: Satellites Images (Field Data 2020)

Figure 4. Kibwezi Forest Land Cover Map for 2018.

The figure 4 shows image of Kibwezi forest boundary 2018 satellites image. It shows the changes in forest composition as represented by different classes shown by different colours. The results of figure 4 were calculated and tabulated as shown in Table 4.

Table 4. Area statistics for Kibwezi forest land cover in 2018.

\begin{tabular}{lll}
\hline Land Cover & Area (ha) & Percent \\
\hline Forest & 3814.41 & 65.25 \\
Shrubs & 1304.41 & 22.31 \\
Wetland & 418.73 & 7.16 \\
Built \& Bare & 308.34 & 5.27 \\
\hline
\end{tabular}

Source: Satellites Images (Field Data 2020)

As shown in Table 6, Kibwezi forest in 2018 was represented by the highest percentage of $65.25 \%$ followed by shrubs which account for $22.31 \%$. Wetland covers an area of $7.16 \%$ while $5.27 \%$ of the area is covered by built and bare.
The reduction of the built and bare land shows improvement of other components of the forest. This represents a positive change in the area under forest which can be attributed to the activities of the CFA who helped in reforesting the forest that had been destroyed before.

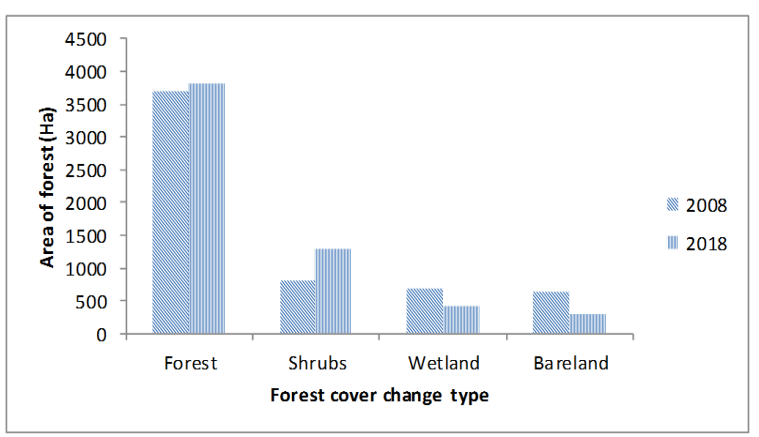

Figure 5. Cover Change among Different Classes.

Table 5. Comparison between statistics for Kibwezi forest land cover in 2008 and 2018.

\begin{tabular}{lllll}
\hline Land Cover & Area ha (2008) & Area ha (2018) & Change (ha) \\
\hline Forest & 3688.67 & 3814.41 & +125.74 & Percentage Change \\
Shrubs & 813.50 & 1304.41 & +490.91 & +03.41 \\
Wetland & 696.22 & 418.73 & -227.49 & +60.34 \\
Bareland & 647.91 & 308.34 & -339.57 & -39.86 \\
\hline
\end{tabular}

Source: Satellites Images (Field Data 2020) 
The finding shown in Table 5 show that land under forest increased from 3688.67 hectares in 2008 to 3814.41 hectares in 2018. This represent a positive $3.41 \%$ forest cover change. The Mean Annual Rate of Forest Cover Change (MARFCC) was calculated as follows;

\section{MARFCC $=\left\{\left(\right.\right.$ forest area at $t_{2}-$ forest area at $\left.t_{1}\right) \div\left(t_{1} \times\right.$ Number of years) $\} \times 100$}

Where $t_{1}$ is Kibwezi forest cover 2008, $t_{2}$ is Kibwezi forest cover in 2018

$$
\{(3814.41-3688.67) \div(3688.67 \times 10)\} \times 100
$$

$$
(125.74 / 36886.7) \times 100
$$

$$
=0.34 \%
$$

This means that area under forest in Kibwezi forest was increasing at a mean annual rate of $0.34 \%$. This is attributed to deliberate actions taken by multi agency groups in Kibwezi forest who include Kibwezi Community Forest Association (KICOFA), David Sheldrick Trust, Kenya Forest Research Institutes (KEFRI) and Kenya Forest Service (KFS). Table 6 show that there is increase in forest while shrubs increased from 813.5 hectares in 2008 to 1304.41 hectares in 2018 representing $60.34 \%$ increase. Shrubs had mean annual rate of change of $6.03 \%$. This represents small trees that have not reached maturity. These trees will grow to become forest with time hence taken to be part of improvement. Shrubs may be as a result of natural regeneration or planted trees in forest. This can be credited to effort made by stakeholders to improve Kibwezi forest cover. The period between 2008 and 2018 was characterized with a lot of improvement in forest cover and shrubs. These findings are in agreement with [8] who postulated that CFA participation leads to improvement of forest cover. Wetlands reduced from 696.22 hectares in 2008 to 418.73 in 2018 representing $39.86 \%$. Bareland reduced from 647.91 hectares in 2008 to 304.34 hectares in 2018 representing $52.41 \%$ change. The effort to restore forest reduced wetlands and the bareland significantly. This can be credited to stakeholders' effort to maintain healthy forest cover. The fencing of Kibwezi forest greatly reduced intrusion in the forest thence improving forest cover. These findings are similar to one by [32] who found that corroboration among stakeholders leads to improvement of forest.

The area under the wetland was 696.22 hectares in 2008 while it changed to 418.73 hectares in the year 2018. The area under wetland reduced by $39.85 \%$ (227.49 ha). This represents mean annual loss of $3.985 \%$ of wetland area. This finding is in agreement with research done by Kiringe (2016) which concluded that the water levels were reducing in Kibwezi forest [21]. This may partially explain why some members of CFA were opposed to taping water from the forest for domestic use by Umani water project.

Bareland reduced from 647.91 hectares in 2008 to 308.34 hectares in 2018. This represents $52.41 \%$ reduction of land in Kibwezi forest that had areas without trees. The trees were planted in areas which were previously classified as bareland hence reducing this class. Most of the areas which had bare lands in 2008 changed into shrubs since it takes long for plants to grow into forest. This implies that there was improvement in the planting of trees in the forest and natural regeneration.

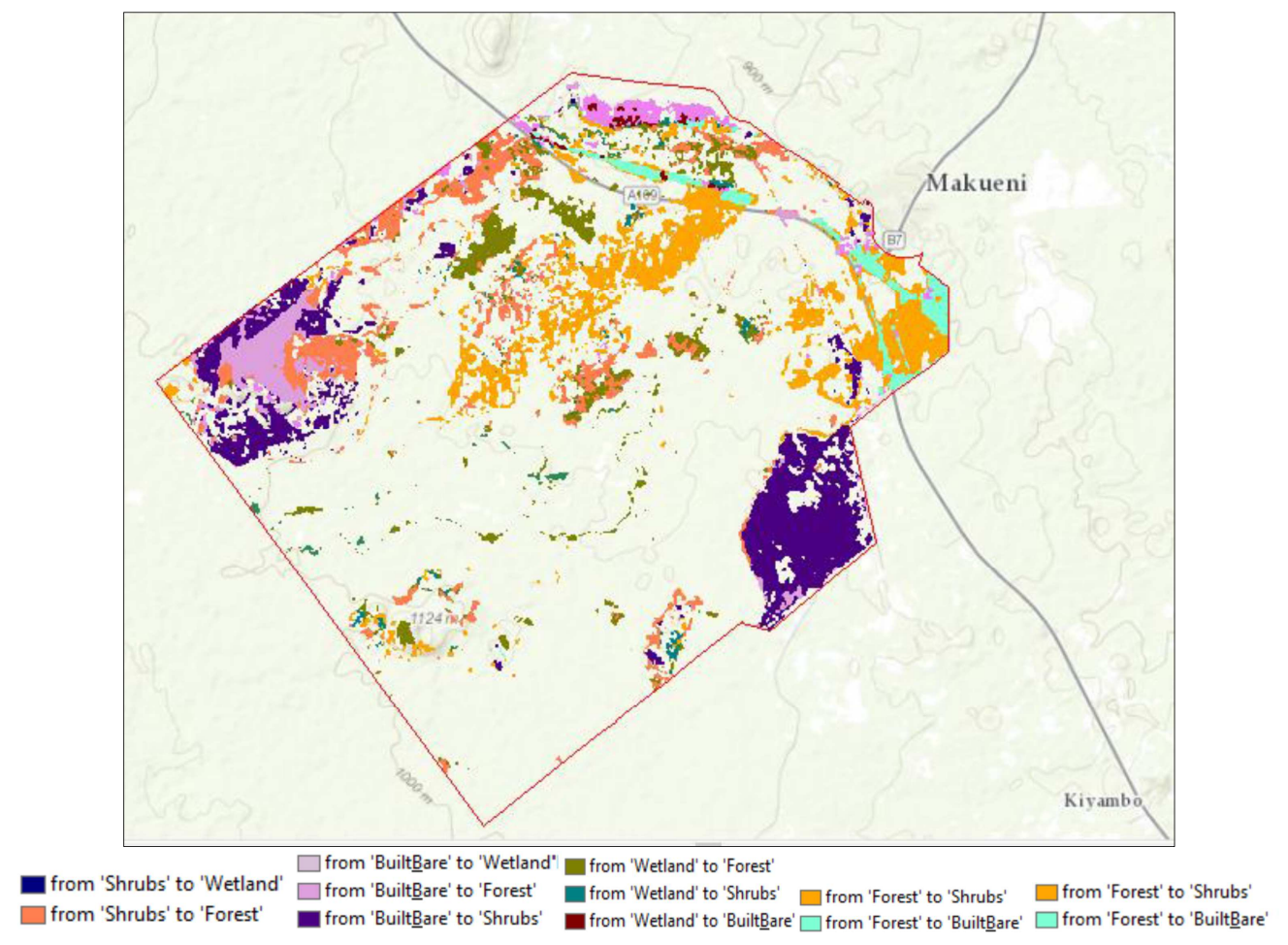

Source: Satellites Images (Field Data 2020)

Figure 6. Thematic Change Map from 2008 to 2018. 
Figure 6 is a representation of thematic map of Kibwezi forest showing how different Classes of forest changed over a period of ten years. The changes were calculated and recorded in Table 6.

Table 6. Analysis of Kibwezi forest land cover change between 2008 and 2018

\begin{tabular}{lllllllll}
\hline Land Cover & Forest & Change (\%) & Shrubs & Change (\%) & Wetland & Change (\%) & Built \& Bare & Change (\%) \\
\hline Forest & - & 0.00 & 43.36 & 4.15 & 11.14 & 0.11 & 78.82 \\
Shrubs & 2.925 & 2.81 & - & 0.00 & 0.47 & 0.10 & 66.29 \\
Wetland & 181.98 & 1.75 & 26.89 & 0.26 & - & 0.00 & 11.36 \\
Bareland & 116.19 & 1.11 & 387.68 & 3.72 & 0.00 & 0.00 & - & 0.16 \\
\hline
\end{tabular}

Source: Satellites Images (Field Data 2020)

Findings from the study as shown in Table 6 indicates that there was change from bareland to shrub a significant area of 387.68 hectares representing 3.72\% improvement. The area around Kithasiu was the most improved. Before coming into force of PFM, the area had been degraded to unimaginable level. This can be credited to the effort by CFA to plant and protect the forest. Shrubs changed to forest by 292.46 hectares representing $2.81 \%$ change.

Infrastructure developments like road, railway and electricity have greatly affected the forest cover through deforestation. This account for the reduction of forest 78.818 hectares as indicated in Table 6 as change from forest to bareland representing $0.76 \%$ as negative change. This is caused by infrastructure development like railway line, offices, hotel and road which have been constructed in Kibwezi forest.

Where there was little forest cover or bareland has been converted to the forest. This is shown in Table 6 whereby the area of 116.19 hectares which was previously built and bare was changed into forest. This may be accounted by effort to regenerate the forest by community forest association, KFS and David Sheldrick Trust.

To test if there was any relationship between community forest participation and improvement, Chi square test was done and the results were as follows, $\left(\chi^{2}=27.631, \mathrm{df}=9\right.$, 0.001 ) since $\mathrm{p}$-value was less than 0.05 , there was strong evidence to support that community participation increases the probability of forest cover improvement. This can be confirmed by positive changes observed from satellites data that shows positive improvement of forest. This also indicates that community participation leads to improved forest cover. These findings agree with $[33,32]$ who asserted that PFM leads to improved forest cover.

\section{Conclusion}

Kibwezi forest has improved significantly due to effort made by CFA and David Sheldrick Trust. CFA should be involved more to improve the forest cover in Kibwezi and other dryland forest. Communities should be allowed to come up with domesticated solution to problems that affect natural resources. Drylands forest faces unique problems hence there is need for greater effort to avoid more destructive activities that may lead to further degradation. These resources should be continuously monitored to strategize on ways of improvising their conservation strategies. Dryland natural resources like Kibwezi forest should be continuously monitored through use of technology. This will document forest change trajectory hence improving on strategy of management. The other stakeholders like the area chief, government agencies and NGOs should have consultative forums where they discuss methods of conserving Kibwezi forest to avoid degradation. Extensive research should be done on the best solution to dryland forest degradation and how to enhance multi-stakeholder engagement.

\section{References}

[1] Newton, A., Costillo, R., C. Premoli, J. B., \& Williums, G. (2012). Forest Landscape Restoration in the Drylands of LatinAmerica. Ecology and Society, 21.

[2] FAO. (2018). FAO's global and regional assessment 19482018. Seventy years of FAO's Global Forest Resources Assessment. Rome: FAO.

[3] FAO. (2015). Global Forest Resources Assessment. Rome: FAO.

[4] Siraj, M., Zhang, K., Xiao, W., \& Bilal, A. (2016). Does Participatory Forest Management Save the Remnant Forest. The National Academy of Sciences.

[5] Mbuvi, M. T. E., (2018). Impacts Of Decentralized Governance On Forest Conservation And Community Livelihoods In Kakamega And Loita Forests, Kenya. Nairobi.

[6] Djoudi, H., Vergles, E., Blackie, R. R., Koame, C. K., \& Gautier, D. (2015). dry land forests, livelihoods and poverty alleviation: understanding current trends. International Forestry Review, 17 (2), 55-69.

[7] Ros-Tonena, M. A., Andelb, T. v., Morsello, C., Otsukid, K., Rosendo, S., \& Scholz, I. (2008). Forest-related partnerships in Brazilian Amazonia: There is more to sustainable forest management than reduced impact logging. Forest Ecology and Management, 16.

[8] Linuma, O., \& Tang'are, J. (2018). Community Perceptions towards Participatory Forest Management, A Case of Kazimzumbwi Forest Reserve in Kisarawe, Tanzania. International Journal of Scientific and Research Publications, 125.

[9] Pokharel, B., Stadtmüller, T., \& Pfund, J. (2010). From degradation to restoration: An assessment of the enabling conditions for community forestry in Nepal. Natural Resources Management, 1.

[10] FAO. (2016). Trees, forests and land use in drylands The first global assessment. Rome: FAO. 
[11] Tadesse, S., Woldetsadik, M., \& Senbeta, F. (2017). Forest Users' level of participation in a participatory forest management program in southwestern Ethiopia. Forest Science and Technology, 163-163.

[12] Ros-Tonen, M. A., Hombergh, H. v., \& Zoomers, A. (2006). Partnerships in Sustainable Forest Resource Management: Amsterdam: Centre for International Forestry Research.

[13] Pellikka, P., Heikinheim, V., Hietanena, J., Schäfera, E., Siljandera, M., \& Heiskanenb, J. (2018). Impact of land cover change on aboveground carbon stocks in Afromontane landscape in Kenya. Applied Geography, 178-189.

[14] Francois, B., Nora, B., Alan, G., \& Danae, M. (2017). The extent of forest. American Association for the Advancement of Science, 635-638. doi: https://doi.org/10.1126/science.aam6527

[15] Tafere, A. (2013). Factors Affecting Forest User's Participation in Participatory Forest Management; Evidence from Alamata Community Forest, Tigray; Ethiopia. Mekell: Mekelle University.

[16] Bekele, M., Bose, P., Burger, K., Fay, P., Kassa, H., Kariuki, P. M., \& Ingram, V. (2016). Forests Management and Social Diversity in Africa and Asia. Springer International Publishing Switzerland, 1.

[17] Matiku, P., Caleb, M., \& Callistus, O. (2013). The impact of Participatory forest management on local community livelihood in Arabuko Sokoke forest, Kenya. Conservation and Society, 112-129.

[18] Kariuki, H., Zanden, E., Malek, Z., \& Verburg, P. (2017). Land cover change and woodland Degradation in a charcoal producing semi-arid area in kenya. Land Degradation \& $d d$ Development, 28 (2), 481-481.

[19] Wekesa, I. W. (2017). Examining th Role of Community Participation in the Forest Management and Conservtion in Kimothon Forest, Tranzoia County, Kenya. Nairobi: University of Nairobi Press.

[20] Government of Kenya. (2010). Constitution of Kenya 2010. Nairobi: National Council for Law Reporting.

[21] Kiringe, J. W., Mwaura, F., \& Warinwa, F. (2016). Characterization of Chyulu Hills Watershed Ecosystem Services in South-Eastern Kenya. Environment and Natural Resources Research, 6 (3). doi: 10.5539/enrr.v6n3p65.
[22] Musyoki, J. K., Mugwe, J., Mutundu, K., \& Muchiria, M. (2016). Factors influencing level of participation of community forest associations in management forests in Kenya. Journal of Sustainable Forestry, 205-216.

[23] Heikkila, T., \& Carter, D. P. (2017). Environmental Science: Common Pool Resources. Oxford doi: 10.1093/OBO/9780199363445-0011.

[24] Hardin, G. (1968). The Tragedy of the Commons. Science, 162. New York Avenue, Washington, DC 20005. doi: 10.1126/science.162.3859.1243.

[25] Ostrom, E. (2002). Self-Governance of Common Pool Resources and Institutions. London: Macmillan Press.

[26] Kenya National Bureau of Statistics. (2009). Kenya Population Housing Census; Population distribution by administrative units (Vol. 1A). Nairobi: Government press. Retrieved 2018.

[27] John, C. (2014). Research design: Qualitative, quantitative, and mixed methods approaches 4th edition. India: SAGE Publications.

[28] Mugenda, O., \& Mugenda, A. (2003). Research Methods: Quantitative and Qualitative Approaches. Nairobi: African Centre fo Technology Studies (ACTS) press.

[29] Ayuyo, I., \& Sweta, L. (2018). Land Cover and Land Use Mapping and Change Detection of Mau Complex in Kenya. International Journal of Science and Research, 2319-7064.

[30] Zang, S., Zhang, B., \& Wu, C. (2014). Review of remote sensing image classification techniques: The role of spatiocontextual information. Eur. J. Remote Sens., 389-411.

[31] Chander, G., Markham, B., \& Helder, D. (2009). Summary of Current Radiometric Calibration Coefficients for Landsat MSS, TM, ETM+, and EO-1 ALI Sensors. Press, Remote Sensing of Environment, Manuscript, RSE-D-08-00684).

[32] Mugambi, D. M. (2019). Fencing and Forest Conservation: Attitudes of Local People. International Journal of Natural Resource Ecology and Management, Vol. 4 (1, 2019), 1-6. doi: 10.11648/j.ijnrem.20190401.11.

[33] Bastin, F. J., Berrahmouni, N., \& Grainge, A. (2017). The extent of forest in dryland biomes. Reports ecology, 365 (6338), 635-638. doi: 10.1126/science.aam6527. 